Intersections

Canadian Journal of Music

Revue canadienne de musique
Intersections CANADIAN JOURAL OF MUSIC

\title{
Marshall Mcluhan and Higher Music Education
}

\section{Glen Carruthers}

Volume 36, numéro 2, 2016

URI : https://id.erudit.org/iderudit/1051593ar

DOI : https://doi.org/10.7202/1051593ar

Aller au sommaire du numéro

\section{Éditeur(s)}

Canadian University Music Society / Société de musique des universités canadiennes

ISSN

1911-0146 (imprimé)

1918-512X (numérique)

Découvrir la revue

Citer cet article

Carruthers, G. (2016). Marshall Mcluhan and Higher Music Education. Intersections, 36(2), 3-11. https://doi.org/10.7202/1051593ar

\section{Résumé de l'article}

Les théories de Marshall McLuhan touchent si bien à l'enseignement et l'apprentissage, qu'elles ont attiré largement l'attention des chercheurs dans le domaine. Malgré leur impact sur Schafer et d'autres chercheurs, on constate pourtant avec surprise la quasi absence d'analyse critique sur leurs implications pour l'enseignement de la musique aux niveaux populaire et avancé. Cette étude contribue à combler ce manque. On y montre que les points de vue provocants de McLuhan ont une portée directe sur ce qui est des environnements formels d'apprentissage, tels que les écoles de musique, qui sont aux prises avec les notions d'inclusivité et d'exclusivité, de musique communautaire et de concert, d'improvisation et d'interprétation textuelle, même lorsque ces établissements travaillent à réformer complétement leurs programmes.
Copyright @ C Canadian University Music Society / Société de musique des universités canadiennes, 2018
Ce document est protégé par la loi sur le droit d'auteur. L'utilisation des services d'Érudit (y compris la reproduction) est assujettie à sa politique d'utilisation que vous pouvez consulter en ligne.

https://apropos.erudit.org/fr/usagers/politique-dutilisation/ 


\title{
MARSHALL MCLUHAN AND HIGHER MUSIC EDUCATION
}

\author{
Glen Carruthers
}

\section{INTRODUCTION}

Over ten years ago, in May 2007, I delivered a paper to the International Society for Music Education European Regional Conference in Piteå, Sweden, and it was subsequently published (Carruthers 2009a).

In researching that paper, I read with interest articles and books by Marshall McLuhan. I was aware that R. Murray Schafer acknowledged a debt to him, despite the former's observation that the latter's lectures were "so poor" (Schafer quoted in Adams 1983, 11). ${ }^{1}$ Schafer's ideas converged with McLuhan's, and there are many references to McLuhan in Schafer's writings. I resolved that, when time permitted, I would pursue the association between these Canadian vanguards in communications theory (McLuhan), and music education and soundscape studies (Schafer). The present article, which focuses on McLuhan, constitutes a preliminary stage in that investigation.

\section{Literature Review: McLuhan ANd Music}

\section{Primary Sources}

Although McLuhan shares Schafer's interest in acoustic space and "auditory imagination" and is much concerned with media that transmit music, including radio, phonograph, audiotape, and television, music arises in McLuhan's writings infrequently. He makes passing reference to Bartok in Explorations 8 ([1957c] 1967, 115) and Orff in The Medium Is the Massage (McLuhan and Fiore 1967, 56), and quotes Ezra Pound's Antheil and the Treatise on Harmony (Stearn 1967, 115) and John Cage (McLuhan and Fiore 1967, 119). McLuhan's aphorisms include musical references: e.g., "A superimposed metronomic time or space pattern is intolerable today in verse, in town planning or in music" (Stearn 1967, 114) and "Man lives in such a sphere of jazzed up rag-time sensuous be-bop"

1 Opinions about McLuhan as a teacher (narrowly and broadly defined) vary tremendously. For a view different from Schafer's, see Black (2010), who quotes both Walter Ong ("Above all and in all and through all, McLuhan was a teacher") and Douglas Coupland ("Marshall was a terrific professor"). 
(Stearn 1967, 115). The bibliography of The Gutenberg Galaxy (McLuhan 1962) includes Alfred Einstein's Short History of Music, Wilfrid Mellers's Music and Society, and Bruce Pattison's Music and Poetry of the English Renaissance. A two-page article, "Jazz and Modern Letters" (McLuhan 1957b), is about the relationship between poetry, speech, and song. The article contains such perplexing observations as "Song is not so much one-person-talking-to-one-person, as many talking to many-a fact which may account for people's lack of interest in the private lives of song writers as opposed to book writers" (72). Folksong is mentioned in a New Yorker cartoon reprinted in The Medium Is the Massage: "You see, Dad, Professor McLuhan says the environment that man creates becomes his medium for defining his role in it. The invention of type created linear, or sequential, thought, separating thought from action. Now, with TV and folk singing, thought and action are closer and social involvement is greater. We again live in a village. Get it?" (McLuhan and Fiore 1967, 156-7).

Three more substantial observations, all concerning melody, appear in the opening chapter of Understanding Media (1964a). This is the chapter famously titled "The Medium Is the Message":

1. People used to ask what a painting was about. Yet they never thought to ask what a melody was about (28).

2. The greatest aid [in avoiding subliminal messages] is simply in knowing that the spell can occur immediately upon contact, as in the first bars of a melody (30).

3. An African who listens to the news in a language he doesn't understand has an "attitude to speech ... like ours to melody-the resonant intonation was meaning enough (34).

It is clear that McLuhan believes in the power of melody; its effect is immediate, seductive, and non-referential. These observations, however, which are not explained, are not directly relevant to the topic at hand. What is relevant is that these quotations, sound bites, cartoons, personal observations, and others like them constitute the sum total of McLuhan's writings about music. He has little to say on the topic, and what he does say is either contentious or inconsequential.

\section{Secondary Sources}

By contrast, in the secondary literature on McLuhan, references to music occur frequently. Several articles in Music Educators Journal in the late 1960 s and early 1970 focus on McLuhan's theories (e.g., Danziger 1970; Eickmann and Fowler 1971). It is curious that J.W. Wilkey's article, "Marshall McLuhan and Meaning in Music," appeared in Music Educators Journal at all. Music education is mentioned only in the closing sentence: "The question is whether or not the musical performer-and the teacher of music performers-will take seriously enough the challenge of McLuhan's message; that the medium is the message" (Wilkey 1969, 58). Wilkey contends that the performer is the message and the medium is music, which is the inverse of the more usual interpretation that music is the message and performance is the medium. What is certain is that McLuhan would have sanctioned neither naive distillation of his complex 
theories. These propositions, in any event, could be parsed only in a discourse on content and meaning in music, which is well beyond the parameters of the present paper.

From McLuhan and music, in primary and secondary sources, we now move to McLuhan and education.

\section{Literature Review: McLuhan and Education}

McLuhan's writings on education, unlike his writings on music, are numerous and insightful. As early as 1956 he addressed "Educational Leadership for a Free World: Mass Media of Communication." The following year, "Classrooms without Walls" appeared. These articles and another dozen or so like them contain important observations, particularly on education and technology.

McLuhan branches into other areas of education, too. The Medium Is the Massage (McLuhan and Fiore 1967) includes a page on "your education" that concludes, "Today's child is growing up absurd, because he lives in two worlds, and neither of them inclines him to grow up. Growing up-that is our new work, and it is total. Mere instruction will not suffice" (18).

This unacknowledged reference to Paul Goodman's Growing Up Absurd: Problems of Youth in the Organized Society (1956) recognizes a tension between the world inside schools and universities and the world outside them. McLuhan had addressed this issue directly a few years earlier in "The University in the Electric Age: The End of the Gap between Theory and Practice" (McLuhan, 1964b). ${ }^{2}$ The separation of learning from living arises again later in The Medium Is the Massage. It takes the form of a quote from John Dewey, written in mirror image: "Compartmentalization of occupations and interests bring about a separation of that mode of activity commonly called 'practice' from insight, of imagination from executive 'doing.' Each of these activities is then assigned its own place in which it must abide. Those who write the anatomy of experience then suppose that these divisions inhere in the very constitution of human nature" (McLuhan and Fiore 1967, 54-5).

McLuhan's thoughts on education are given fullest voice in 1977, when he appears as one of three co-authors, including his son Eric, of a textbook entitled City as Classroom: Understanding Language and Media (McLuhan, Hutchon, and McLuhan 1977). Tellingly, there are chapters on cars, newspapers, magazines, books, light bulbs, photographs, films, television, radio, telephones, clocks, computers, airplanes, satellites, money, and so forth, but music is hardly mentioned and music education not at all. Although McLuhan flirts with music and dances with education, the manner in which his theories might affect music education is never considered.

2 Co-curricular records, peer assessments, prior learning assessment, work placements, and experiential learning seek to align the worlds inside and outside institutional learning. Popular music programs, and more recently community music programs, have been to varying degrees successful in this regard. 


\section{Discussion: McLuhan and Music Education}

I will use three questions to frame concepts seminal to McLuhan's thinking that have direct bearing on higher music education.

1. Although the term global village did not originate with McLuhan, it has been associated with him since the early 1960 s (i.e., from The Gutenberg Galaxy onwards). ${ }^{3}$ The global village presents a conundrum for higher music education. If all musics are accessible via the internet, if computer-assisted learning links communities across time and space, and if non-formal, informal, and other modes of learning challenge fundamental precepts of formal learning, what role, if any, remains for legacy music teaching and learning institutions? Much has been written on this topic, and a recent issue of Arts and Humanities in Higher Education was devoted to it ("Reflective Conservatoire" 2016). This is also the subject of Peter Tregear's Enlightenment or Entitlement?: Rethinking Tertiary Music Education (2014).

2. Jacques Ellul, writing in 1964, offered his opinion that technology is "of necessity, our universal language" $(1964,132)$. Has music-touted glibly as a universal language-lost ground to technology as a tie (or perhaps the tie) that binds communities together? If so, what does this mean for higher music education and music in higher education?

3. Curricula that continue to emphasize reading music at the expense of making music fall prey to the limitations of "typographic man" (see McLuhan 1962). McLuhan maintains that print media are limiting and create regional cultures, and electronic media are delimiting and create a global culture. If McLuhan is correct, what are the implications for higher music education?

These three questions and their answers are co-dependent, but, with this in mind, in the interests of concision, I will consider only one question-the last one.

\section{Music and Print Culture}

Music in higher education in the Western world is and always has been preoccupied with text. This preoccupation is manifest in at least two ways:

1. We describe and analyze notated music. We are, in effect, replacing one text (a notated score) with another (a gloss on a notated score).

2. Making music involves rendering musical texts audible in real time; in this way, making music and interpreting texts have become synonymous.

3 The term was likely coined by Wyndham Lewis in America and Cosmic Man (1948). 
To use McLuhan's terminology, higher music education focuses on the visual extension of an aural medium. This phenomenon is typical of typographic man. "The dominant organ of sensory and social orientation in pre-alphabet societies was the ear-'hearing was believing.' The phonetic alphabet forced the magic world of the ear to yield to the neutral world of the eye. Man was given an eye for an ear" (McLuhan and Fiore 1967, 44).

The limitations of text-spoken or written-arise, ironically, frequently in literature. Writers throughout history have addressed the limitations at best and perversity at worst of words. As an example, Andreï Makine, a writer from Siberia who sought political asylum in France and is best known for Dreams of My Russian Summer and The Crime of Olga Arbyelina, writes, "And I had already had my European education. I had already tasted the terrible Western temptation of the word. 'What is not said does not exist!' this tempting voice whispered to me" $(1999,183)$.

British novelist Penelope Fitzgerald said, "But she knew also that her uncle, like most men, believed that what had not been put into words, and indeed into written words, was not of great importance" $(1995,142)$.

Aldous Huxley had gone further than either Makine or Fitzgerald to link language with madness and diabolism: "'In the beginning was the word.' So far as human history is concerned, the statement is perfectly true. Language is the instrument of man's progress out of animality, and language is the cause of man's deviation from animal innocence and animal conformity ... into madness and diabolism. Words are at once indispensable and fatal" ([1952] 2009, 300).

While McLuhan may take exception to the notion that "in the beginning was the word," although he was a practising Catholic, that is not the point. The point is that, in the same way that text is neither neutral nor innocuous, so our reliance on text is neither neutral nor innocuous.

The inherent danger of employing one medium as proxy for another has been explored widely, often with reference to McLuhan. James W. Carey ([1967] 1969, 270ff) offers insights into the rift between sensory and print media relevant to the discussion of music. A decade later, John Shepherd et al. linked the disconnect between sensory and print media to the Western propensity to equate reduction with comprehension: "Everything is rationally explicable when reduced to the appropriate analytic constituents. Anything which cannot be so reduced and which therefore cannot be made visually explicit, immediately becomes non-knowledge" $(1977,132)$.

Barton McLean acknowledges that a "primary characteristic of humans [is] to become absorbed and engrossed in their extensions systems" (1981/1982, 336). We need food in order to survive and we turn food into art. We need sounds in order to communicate and we turn sounds into music. So far so good.

It is the next step that is perilous. In order to share recipes, we write them down. In order to share music, we write it down. We then engage an intermediary-a cook or performer-to reconstitute in edible/audible form instructions that exist for the eye, as a conduit to the taste buds or ear. 
Reconstituting music in this way has become fundamental to higher music education. The real work of imagining music is relegated to a select group of students (primarily composers and improvisers). In practical studies, for most students outside contemporary commercial music, jazz, world music, or community music, the goal is to become skilled at translating one medium (print) into another (sound). ${ }^{4}$ When the eye replaces the ear, music becomes separated from its sound source. Print is an intermediary that can inhibit interaction between subject (in this case, the student) and object (in this case, the music). To put this in McLuhan's terms, in this shift from aural to print culture the medium easily subsumes the message.

Earlier I explored the ways and means technology emancipates music from its symbolic extensions (Carruthers 2009a). Elsewhere I have discussed how musical performances capture and freeze otherwise viscous art works. The argument in these papers, although germane to the present discussion, won't be repeated here (see Carruthers 2008, 2009b, 2009c). Suffice it to say (and here I was referring to school music education, but it pertains to higher music education too), that "for many students, creativity can be given freer rein when notation neither precedes nor follows making music. This is true, not only because learning to decipher notation has nothing to do with learning to create music (completely different skill sets are involved), but also because the imprecise nature of musical notation is a limiting factor for most non-expert musicians [which is what students are]. Expert musicians can hear the music beyond the notes. Non-expert musicians can't hear the music because of the notes" (Carruthers 2009a, 6).

Is it this simple-experts benefit from text, non-experts don't, and students are situated on a continuum between these extremes? Of course, the answer is more complex than this, but in most higher music education curricula the gap between rendering captured music and composing or improvising music anew is neither broached nor breeched. Although in recent years courses and programs have been introduced in which music's social relevance, for example, is emphasized far more than the analysis and performance of pre-composed music, most programs, in emphasizing capturing and recapturing music, on paper and in performance, continue to valorize music's symbolic extensions. To move beyond this will require a sea change in higher music education.

\section{ConClusion}

Public intellectuals have always played an ambiguous role in academe. By definition, their theories have wide popular appeal and can often be applied across and between disciplines. When MusCan (then CUMS) met as part of Congress at UBC in 2008 I attended a lecture by Richard Florida. I was struck by the relevance to universities of much of what Florida said about cities. This transferability, typical of Florida's thinking, is typical of McLuhan's as well.

4 The relationship between musical performance and literary translation is explored in Carruthers (2008). 
McLuhan warned of the dangers of what magicians call misdirection-of diverting attention away from something by making it less present and less attractive than something else. This is the case when music study becomes resolutely text-based.

We are fortunate that Schafer was, among much else and perhaps unwittingly, a musical spokesperson for McLuhan. But Schafer's influence has been much greater on music in schools than on music in universities. Many university music programs remain exemplars of what McLuhan and Schafer, like Christopher Small (1980), decry. Their curricula divert attention from music's sounds to its symbols. Had Schafer been more concerned with higher music education, and had McLuhan's theories, whether distilled by Schafer or not, gained greater traction among higher music educators, the music curricular core in Canadian universities might have strayed earlier, further, and irrevocably from printed texts and the mighty triumvirate of music history, music theory, and performance.

\section{REFERENCES}

Adams, Stephen. 1983. R. Murray Schafer. Toronto: University of Toronto Press. Black, David. 2010. "McLuhan the Teacher." English Studies in Canada 36 (2/3): 24-26.

Carey, James W. (1967) 1969. "Harold Adams Innis and Marshall McLuhan." Originally published in Antioch Review 27 (1). Reprinted in McLuhan Pro and Con, edited by Raymond Rosenthal, 270-308. Baltimore: Penguin Books.

Carruthers, Glen. 2008. "Musical Interpretation and 'The Historical Imagination." Paper presented to the American Musicological Society Midwest Chapter, National-Louis University, Chicago, 4 October.

—. 2009a. "Engaging Music and Media: Technology as a Universal Language." Research \& Issues in Music Education 7 (1). http://www.stthomas. edu/rimeonline/vol//carruthers.htm.

. 2009b. "A New Take on Recurrent Questions: The Ontology of Musical Recordings." Paper presented to the American Musicological Society Midwest Chapter, National-Louis University, Chicago, 17 October.

-2009c. "Recordings in a Diachronic Continuum: Embodying the Musical Past." Paper presented to the International Musicological Society, Conservatorium van Amsterdam, 7 July.

Danziger, Harris. 1970. "Music for the Children of Marshall McLuhan." Music Educators Journal 57 (2): 20-24.

Eickmann, Paul E., and Charles B. Fowler. 1971. "Senses, Media, and Education." In "Technology in Music Teaching," special issue, Music Educators Journal 57 (5): 33-35.

Ellul, Jacques. 1964. The Technological Society (originally published in 1954 as La Technique ou l'enjeu du siècle). New York: Vintage Books.

Fitzgerald, Penelope. 1995. the blue flower. New York: Houghton Mifflin. 
Florida, Richard. 2008. "Who's Your City?" Presentation to Congress, Canadian Federation for the Humanities and Social Sciences, University of British Columbia, 5 June.

Goodman, Paul. 1960. Growing Up Absurd: Problems of Youth in the Organized Society. New York: Vintage Books.

Huxley, Aldous. (1952) 2009. The Devils of Loudun. New York: Harper Perennial Modern Classics.

Lewis, Wyndham. 1948. America and Cosmic Man. London: Nicholson \& Watson.

Makine, Andreï. 1999. once upon the river love. Translated by Geoffrey Strachan (originally published in 1994 as Au temps du fleuve Amour). London: Penguin Books.

McLean, Barton. 1981/1982. "Symbolic Extension and Its Corruption of Music." Perspectives of New Music 20 (1/2): 331-56.

McLuhan, Marshall. 1956. "Educational Leadership for a Free World: Mass Media of Communication." Teachers College Review 20 (4): 566-75. -.(1957a) 1967. "Classrooms without Walls." Explorations 7: Studies in Culture and Communication. Reprinted in Stearn, McLuhan: Hot and Cool, $119-23$.

_.1957b. "Jazz and Modern Letters." Explorations 7: Studies in Culture and Communication, edited by Edmund Carpenter and Marshall McLuhan, 74-6.

_- (1957c) 1967. "Verbi-voco-visual." Explorations 8: Studies in Culture and Communication. Reprinted in Stearn, McLuhan: Hot and Cool, 114-18.

. 1962. The Gutenberg Galaxy: The Making of Typographic Man. Toronto: University of Toronto Press.

- 1964a. Understanding Media: The Extensions of Man. New York: McGraw-Hill.

_ 1964b. "The University in the Electric Age: The End of the Gap between Theory and Practice." Varsity Graduate 11 (3): 60-4.

McLuhan, Marshall, and Quentin Fiore. 1967. The Medium Is the Massage: An Inventory of Effects. Co-ordinated by Jerome Agel. New York: Bantam Books.

McLuhan, Marshall, Kathryn Hutchon, and Eric McLuhan. 1977. City as Classroom: Understanding Language and Media. Agincourt, ON: Book Society of Canada.

"Reflective Conservatoire." 2016. Special issue, Arts and Humanities in HigherEducation 15 (3/4). http://www.artsandhumanities.org/journal/ahhe-special -issue-june-2016/.

Shepherd, John, Phil Virden, Graham Vulliamy, and Trevor Wishart. 1977. Whose Music? A Sociology of Musical Languages. London: Latimer New Dimensions.

Small, Christopher. 1980. Music, Society, Education. London: John Calder.

Stearn, Gerald Emanuel, ed. 1967. McLuhan: Hot and Cool-A Primer for the Understanding of \& a Critical Symposium with a Rebuttal by McLuhan. New York: Signet Books. 
Tregear, Peter. 2014. Enlightenment or Entitlement?: Rethinking Tertiary Music Education. Platform Papers no. 38. Strawberry Hills, NSW: Currency House.

Wilkey, Jay W. 1969. "Marshall McLuhan and Meaning in Music." Music Educators Journal 56 (1): 54-58.

\begin{abstract}
The way in which Marshall McLuhan's theories relate to teaching and learning broadly has garnered scholarly attention. It is surprising, though, given his impact on Schafer and others, that there is scant critical commentary on the implications of McLuhan's theories for either mass music or higher music education. The present study is a step towards redressing this gap. The study concludes that McLuhan's iconoclastic views have direct bearing on formal learning environments, like music schools, that struggle with notions of inclusivity and exclusivity, community music and concert music, improvisation and textual interpretation, even as they embrace timely and sweeping curricular reform.
\end{abstract}

\title{
RÉSUMÉ
}

Les théories de Marshall McLuhan touchent si bien à l'enseignement et l'apprentissage, qu'elles ont attiré largement l'attention des chercheurs dans le domaine. Malgré leur impact sur Schafer et d'autres chercheurs, on constate pourtant avec surprise la quasi absence d'analyse critique sur leurs implications pour l'enseignement de la musique aux niveaux populaire et avancé. Cette étude contribue à combler ce manque. On y montre que les points de vue provocants de McLuhan ont une portée directe sur ce qui est des environnements formels d'apprentissage, tels que les écoles de musique, qui sont aux prises avec les notions d'inclusivité et d'exclusivité, de musique communautaire et de concert, d'improvisation et d'interprétation textuelle, même lorsque ces établissements travaillent à réformer complétement leurs programmes.

\section{BIOGRAPHY}

Dr. Glen Carruthers has been dean of Music at Wilfrid Laurier University since 2010. He has published in the fields of musicology and post-secondary music education and has presented conference papers and guest lectures internationally. Carruthers is past chair of the ISME Commission on the Education of the Professional Musician. He served on the board of MusCan for many years and was named an honorary member of the society in 2016. 